\title{
Managerial Practices that Support Lean and Socially Sustainable Working Conditions ${ }^{\prime}$
}

\section{Malin Håkansson ${ }^{2}$}

PhD-student, School of Technology \& Health, KTH-Royal Institute of Technology, Stockholm, Sweden

\section{Richard J. Holden}

Assistant professor, School of Informatics and Computing-Indianapolis, Indiana University,USA

\section{Andrea Eriksson}

Assistant professor, School of Technology \& Health, KTH-Royal Institute of Technology, Stockholm, Sweden

\section{Lotta Dellve}

Professor, Department of Sociology and Work science, University of Gothenburg, Gothenburg, Sweden

\begin{abstract}
Despite decades of using lean, there is little knowledge of how lean managerial practices affect working conditions. Thus, the aim of this study was to investigate in what ways managerial practices support socially sustainable working conditions (SSWCS) during a lean transformation. A mixed methods approach was used in this multiyear case study in a midsize Swedish manufacturing company. Assessment of work characteristics was combined with employee questionnaires and interviews with managers. Four practices were identified as instrumental for SSWCS: I) a coherent lean approach with clear direction, 2) a value-creating leadership style comprising a participatorypromoting and caring leadership approach with joint focus on production and well-being, 3) conscious involvement of employees in a stepwise fashion, and 4) a focus on promoting meaningful jobs and health, aided by work environment management. Thus, managerial practices actively supporting important job resources as an integral part of the lean system seemed to support SSWCS.
\end{abstract}

\section{KEYWORDS}

Employee effects / lean production / managerial practices / sustainability / working conditions

\section{Introduction}

espite decades of using the management concept of lean production in industry, there is little knowledge about which managerial practices promote those lean implementations that support socially sustainable working conditions (SSWCs). Here, SSWC is broadly defined as a work environment with sufficient job resources

\footnotetext{
${ }^{1}$ You can find this text and its DOI at https://tidsskrift.dk/njwls/index.

${ }^{2}$ E-mail: malin.hakansson@sth.kth.se.
} 
to support meaningful work, employee growth, and health (Kira \& Forslin, 2008; Schaufeli \& Bakker, 2004). Lean production (henceforth lean) is a Toyota-inspired multidimensional production and management concept (Hines et al., 2004; Liker, 2004; Womack et al., 1991). Several studies confirm that lean is associated with improvements in productivity, quality, and profitability (Liker, 2004; Shah \& Ward, 2003). However, lean has been linked to work intensification (Westgaard \& Winkel, 2011), and several studies on lean and working conditions report worsened social conditions (Hasle, 2014; Koukoulaki, 2014; Landsbergis et al., 1999). Some of these studies have also indicated that lean can have mixed effects on working conditions, depending on management style, implementation approach, cultural differences, and type of organization (Hasle, 2014; Koukoulaki, 2014). Thus, the need for detailed studies of how lean can be implemented to promote favorable employee working conditions has been indicated (Hasle et al., 2012). Understanding what may support SSWC, even in a lean work system with high performance demands, is important because 1) this way of organizing work is a trend in contemporary work life (Parker, 2014; Samuel et al., 2015; Westgaard \& Winkel, 2011); and 2) work-related health problems are a major public health concern (Eurofound, 2012).

\section{Background}

\section{Lean and managerial practices}

Lean can be present at different organizational levels, both as a philosophy and a set of tools (Pettersen, 2009; Shah \& Ward 2007). Important aspects of lean thinking include increasing customer value by identifying value-adding activities and eliminating unnecessary working processes (Liker, 2004; Womack \& Jones, 2003). Examples of organizational lean tools are defining corporate values, 5S-a system for structuring the workplace, policy deployment, standardization of work processes, lean boards used for visual steering, and value stream mapping (VSM) for identifying and analyzing how work processes can be simplified and improved (Dennis, 2007). Lean leadership practices also commonly include the implementation of lean tools aimed at promoting employee engagement in daily learning, and systematic continuous improvements (CIs) and monitoring of results (Liker, 2004; Womack \& Jones, 2003). Swedish lean initiatives traditionally have a strong focus on employee involvement (Brännmark \& Eklund, 2013) and employee coaching during lean implementation (Andreasson et al., 2015). An overview of Nordic studies on management behaviors and working conditions (Torvatn et al., 2015) concluded that surprisingly few studies in this field have investigated modern organizational methods like lean. Only a few studies have empirically studied and described lean leadership (Liker \& Convis, 2012; Poksinska et al. 2013; Vänje \& Brännmark, 2015). The importance of lean leadership practices may vary depending on different organizational contexts, including maturity and resources for employees engaging in change (Eriksson et al., 2016), and how well lean leadership practices are translated and adapted to the organizational context (Langstrand, 2012). The literature separates the concepts of leadership and management. Management is described as a formal system of implementing and evaluating organizational goals. Leadership embraces an informal role of inspiring employees to engage in organizational goals (Kotter, 1990). Previous

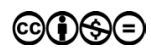


research points out that lean requires a vision-driven, engaged, and a close-to-practice leadership approach (Brandao de Souza, 2009; Liker, 2004; Radnor \& Walley, 2008). Emiliani (1998) suggests, for example, that lean leadership needs to entail leadership activities that promote participation and employee empowerment. Liker and Hoseus (2008) described servant leadership, which supports and serves employees, as important in Toyota leadership culture. Liker and Convis (2012, pp. 31-32) describe the following four main stages/activities for Toyota leaders:

(1) self-development by harmonizing with the company's values and learning from the work practices (gemba), where the actual work is performed;

(2) coach and develop others by creating situations for learning and by taking responsibility for helping others self-develop;

(3) support daily kaizen by promoting learning of leadership skills down through the organization and identifying gaps between work planned and work done;

(4) create a vision and align goals through a collaborative process and by sustained work with CIs and a focus on solving problems and developing people.

These descriptions of ideal lean leadership are similar to transformational leadership (Bass, 1990), which is associated with job satisfaction and employee well-being (Skakon et al., 2010). A darker side of lean management practices is presented by Mehri (2006). He described a culture where 'Safety number one!' was only a hollow façade and went on to describe authoritarian hierarchies, employees being humiliated in front of others, plant layouts with not enough safety space, high-paced work with no breaks, and high rates of work-related illnesses.

Regarding employee value streams, Liker and Hoseus (2008) state that only work that contributes to development and learning can be classified as value-adding work. In turn, Emiliani (1998) defines lean leadership behaviors as 'behaviors that create value' (p. 619). For example, clear instructions are seen as a behavior that supports work flow. By creating value for employees, managers may thereby promote employee behaviors that in turn aid in achieving business goals (von Thiele Schwarz \& Hasson, 2013). The perspective on lean leadership in this article concerns how leadership and management of lean is practiced and shaped by daily activities and interactions between individuals and groups in an organization (Alvesson \& Sveningsson, 2003). A management practice perspective is used (Tengblad, 2012), focusing on managers' acts of organizing, which, for example, contribute to the structuring of activities, relationships, and interactions in the organization (Hosking, 1988). All acts of organizing are hereafter refered to as managerial practices. These include leadership practices supporting symbolic activities (meaning in work), and substantive activities (mangerial work focusing on concrete structural changes) (Denis et al., 2001).

\section{Lean and organizing socially sustainable working conditions}

Most prior studies point at factors in lean implementations that jeopardize the development of SSWC (Hasle, 2014; Koukoulaki, 2014; Landsbergis et al., 1999; Oudhuis $\&$ Tengblad, 2013). Regarding research on lean and employee control, the majority of studies report restricted employee control in lean companies (c.f. Jackson \& Mullarkey, 
2000; Lewchuk et al., 2001; Parker, 2003; Schouteten \& Benders, 2004). Only a few studies indicate increased autonomy (Nielsen, 1996; Saurin \& Ferreira, 2009; Seppälä \& Klemola, 2004). Organizations can implement lean in many ways and with different goals (Pettersen, 2009). Therefore, as suggested by Holdens's (2011) model of a lean work system and Parker (2003), different lean implementations may differently transform work design and in turn, bring forth differing effects on employee and company outcomes. In addition, preconditions established by management are suggested to be essential for the success of lean transformations, and depend upon what managers actually do (Mann, 2009). In a similar vein, a study by Nielsen et al. (2008) suggests that perceived work characteristics such as role clarity, opportunities for development, and having a meaningful work environment partially mediate the relationship between a transformational leadership and employee mental well-being. Thus, the present study adopts a systems view on the managerial practices in relation to how they interplay with the chosen lean practices, the work design, and employee participation.

Social sustainability in working life can be viewed as a work system with a sustained functional capacity: 'the ability of employees, groups, and organizations to keep on functioning in any situation faced' (Kira \& van Eijnatten, 2009, p. 234). In order to stimulate functioning, they emphasize the importance of promoting the simultaneous development of different stakeholders in the organization, in line with other stakeholder models (Eklund, 1998), and the dual goal of ergonomics/human factors to promote well-being and performance (Dul et al., 2012). Job designs that humanize work and promote democracy through 'joint optimization of the social and technical systems' are also emphasized in the sociotechnical tradition (Cherns, 1987; Klein, 2014). Kira and van Eijnatten (2009) further suggest that a socially sustainable organization needs to continuously promote the growing complexity of work, and empower employees. Examples of achieving this are through providing employees with sufficient job resources, opportunities to influence their job design, and supporting a sense of meaning to the work. The work factors mentioned are similar to what has been suggested for 'good jobs' or favorable psychosocial working conditions (Bakker \& Demerouti, 2007; Kristensen, 1999). Through analogy to environmental sustainability, sustainable work can also be described as resource regenerative-work that supports the growth rather than the consumption of employees' resources and capacity to deal with future challenges (Kira \& Forslin, 2008). Building on the above-mentioned theories, we broadly define SSWCs as a work environment with sufficient job resources to support meaningful work, employee growth, and health (Kira $\&$ Forslin, 2008; Schaufeli \& Bakker, 2004). The literature offers limited insight into the conditions that could facilitate lean-related improvements that also support the development of SSWC. Previous studies have associated more favorable lean initiatives with more human-oriented lean-approaches, with a focus on human resources (Longoni et al., 2013), employee participation, social support, and inclusive management approaches (Westgaard $\&$ Winkel, 2011). Furthermore, some suggest lean may have more favorable employee outcomes in Scandinavian implementations (Brännmark \& Håkansson, 2012; Sederblad, 2013; Seppälä \& Klemola, 2004). This is due to the Scandinavian tradition of sociotechnical work design (Johansson \& Abrahamsson, 2009). Therefore, studying lean in Swedish organizations is of particular theoretical value. However, previous studies do not report the specific ways managerial practices may support SSWC under lean manufacturing. Thus, this case study is thought to contribute to context-sensitive analysis of managerial practices in relation to how SSWC is shaped in a Swedish midsize manufacturing company

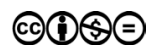


during a lean transformation. The analysis of the findings from the present case focuses on the following research question:

In what ways can managerial practices support socially sustainable working conditions during a lean transformation?

\section{Research methodology}

\section{Study design}

A midsize family-owned Swedish manufacturing company that engaged in small-scale production and had adopted lean was chosen for this 3-year in-depth case study. The company was part of a larger study about lean and employee working conditions. It was chosen because it had achieved social sustainability and success with lean indicated by the continued use of lean for 5 years, postimplementation improvements seen in productivity and financial returns, and sustained favorable psychosocial working conditions (Håkansson et al., 2017). The company's lean transformation was seen as socially sustainable in the sense that many important psychosocial job resources (Kristensen, 1999) and self-rated health assessments were maintained, while others were even developed. For example, social support, recognition, meaning of work, and predictability were maintained at high levels, alongside not too high or too low work demands. This was despite the fact that task control decreased owing to increased work standardization. To explain the positive employee outcomes in this company, a systems approach concerning context, particularly inner context (i.e., organizational structures and company culture) (Pettigrew, 1987), was applied. To achieve triangulation, or a more valid understanding of study phenomena by leveraging multiple sources of data and multiple perspectives (Stake, 1995), a multi-method and multilevel approach was used. Each year, interviews were conducted with three managers and three employees (18 interviews in total). The interviews were complemented with employee questionnaires, a tour of the production site, and document analysis. The study period lasted from 2010 to 2012, and data were collected in April each year. The regional ethics board approved the study, number 2009/767-31/5, and participation required informed consent.

\section{The company studied and its lean implementation}

The company studied, henceforth referred to as VPC, is a Swedish midsize family business. Their mechanical workshop specializes in the manufacture, welding, and assembly of stainless steel products. Their management before lean was traditional, described by the managers as 'management by common sense'. Planning was performed using a material planning system and Excel. The workshop had a functional layout based on grouping of machines according to type. The operators were skilled craftsmen. The lean implementation at VPC started in 2007 with the support of a national development program intended to help industrial companies implement lean, called the Production Leap (Hillberg, 2012). The program offered university courses for participating companies and provided 500 consulting hours by special 'lean coaches' allocated to each company. A steering group 
composed of two lean coordinators from the company, two lean coaches from the program, and a union representative, led the first phase of the implementation with steady support from the CEO. In 2007, as one of the first lean activities, the company's core values were formulated. One-piece flow could not easily be achieved in the company due to a diversity of products and therefore different process times. Moreover, VPC had continued to build inventory for its high-volume season to meet customer and employee demands. VPC's lean practices were instead focused on reducing stock levels, batches, and set-up times. The following lean tools were used and adapted to fit the company's needs: CI, standardization of work, visual planning, performance measurements, set-up time reduction (SMED), cross-training, and VSM. In addition, since 2009, all departments had been applying 5S for the organization of their workplaces. During the study period of 20102012, the company had about 60-80 employees, and they were in an expansion phase; net sales increased by almost $40 \%$, and in the last year of the study, they made plans to expand the shop floor area. Since the start of lean, productivity had increased, corresponding with a staff reduction of about 10 employees. At the beginning of the study, the company had worked successfully with lean for 3 years. Even prior to lean, the organization was rather mature, with experience from previous successful change projects, such as the implementation of ISO 14000 and ISO 9001. With ISO, they had already started to structure their processes and initiated CI efforts. The chief executive officer (CEO) therefore viewed lean as the next natural step after ISO. In addition, VPC had worked systematically with health and safety management for more than 20 years.

\section{Interviews with managers}

Semi-structured interviews about lean practices, other technical and organizational changes, and employee working conditions were conducted annually with the two lean coordinators-the production manager (PM) and an industrial engineer (the latter had become manager of production technology in 2012)-and the CEO. Interviews were conducted onsite and lasted 1-2 hours. The interview guide was divided into different themes and covered general questions about the company, its production, occupational health and safety management, as well as details about its lean practices, that is, the goals sought, the lean tools used, and the results obtained. To capture descriptions of the company's lean practices, a lean index developed by Eklund et al. (personal communication, 2010) that was based on the most commonly described lean characteristics compiled by Pettersen (2009) was used: 1) values at the workplace, 2) customer orientation, 3) teamwork, 4) meeting structures, 5) CIs, 6) just-in-time practices, 7) waste reduction, 8) employee involvement and respect for the employee, 9) VSM, 10) standardized work, 11) housekeeping through 5S, and 12) visual management.

\section{Interviews with employees}

A semi-structured theory-guided interview called ARIA, a Swedish acronym for work content analysis (Waldenström, 2007), was used to capture employee descriptions of management support, of other employee resources for completing their work assignments, and of their involvement in the company's lean activities. The studied aspects are related to 
the job-demands resources model (Demerouti et al., 2001) and stress theory (Corin \& Björk, 2016; Kompier, 2003), and thus employee development and health. The interview aimed at getting as factual, concrete and neutral a description of the work's contents and lean practices as possible (ibid.). A subset of the ARIA themes was included in this study: opportunities for development, influence through CIs, social support, and work goals. The ARIA interview was combined with lean themes chosen from the aforementioned lean index, which was referred to as a Lean ARIA. The lean practices focused on in this company were CIs, 5S, values at the workplace, teamwork, and meeting structures. Three employees were interviewed each year. According to ARIA guidelines, the chosen employees represented the most typical occupations in the company and were experienced (time of employment was 4-7 years at the start of the study), but average employees. Two welders representing different departments (one of them was a working first-line manager) and one employee from packaging were interviewed. The interviews lasted about 1-1.5 hours. At the end of each interview, a summary was made of the descriptions to validate them with the employee.

\section{Questionnaire}

Each year, the same questionnaire was handed out to all employees in three out of seven departments, which had been chosen for their willingness to take part in the study and on account of their active work with lean. Characteristics of the respondents are summarized in Table 1. A subset of indexes from the validated Copenhagen Psychosocial Questionnaire [COPSOQ II; (Pejtersen et al., 2010)] concerning leadership and values at the workplace were included to reflect the organizational social capital in the organization (Gylling Olesen et al., 2008), which, in turn, has been directly associated with employee health (Kivimäki et al., 2003). Here, it is operationalized as employees' views on quality of leadership, justice, and respect, vertical trust between employees and managers, horizontal trust between employees, commitment to the workplace, social community at work, and job insecurity. Most items were assessed using a 5-point scale extending from 'To a very large extent' to 'To a very small extent'. Items related to social community at work and one item regarding commitment to the workplace were assessed using another 5-point scale from 'Always' to 'Never/Hardly ever'.

\section{Document collection and production site tour}

Some key performance indicators (KPIs) from annual reports and compilations by the PM were included to reflect how far VPC had come in its lean implementation. Each year of the study, a tour of the production site was conducted with the CEO for 30-45 minutes. The focus was on the work environment, visual management, and 5S. Photos and notes were used for documentation.

\section{Data analysis}

The interview data were analyzed in several steps and multiple sources were combined. The transcribed interviews were iteratively read through and then coded using 
Table I Characteristics of respondents and number of respondents

\begin{tabular}{lccc}
\hline & \multicolumn{3}{c}{ Year } \\
\cline { 2 - 4 } Questionnaire & $\mathbf{2 0 1 0}$ & $\mathbf{2 0 I \mathbf { ~ }}$ & $\mathbf{2 0 I \mathbf { ~ }}$ \\
\cline { 2 - 4 }$(\mathrm{n})$ & 18 & 23 & 26 \\
Response rate (\%) & 100 & 96 & 96 \\
Mean age & 42.2 & 40.2 & 38.5 \\
Sex, males (\%) & 89 & 87 & 85 \\
Years in profession & 12.2 & 7.3 & 9.4 \\
Interviews & & & \\
Employees (n) & 3 & 3 & 3 \\
Managers (n) & 3 & 3 & 3 \\
\hline
\end{tabular}

a qualitative content analysis approach (Graneheim \& Lundman, 2004). The research question guided the coding and analysis (Kvale \& Brinkmann, 2009). To obtain descriptions of their managerial practices, the content of both manager and employee interviews was coded into main themes. Descriptions of management practices were identified with a focus on examples of what the company was doing in terms of managing and leading the lean practices, more specially, how the CI practices were developed and supported over time. The analysis thus focused on positive managerial practices supporting engagement and health in the organization. To understand the inner organizational context in which the changes occurred, organizational factors interpreted as important for the transformation in general were also identified. In order to analyze the relationships between working conditions and management approaches, the main themes were further analyzed, condensed, and coded into subthemes (latent content). The questionnaire data were used to confirm of the descriptions of the social climate. A software for qualitative research, NVivo 9.2 (QSR International, Melbourne, Australia), aided in the coding.

The software SPSS Statistics 19 (IBM, Stockholm, Sweden) was used to analyze the questionnaire data. The COPSOQ II items were scored on a scale of 0-100, and turned into multi-item scales. The scales were then averaged in accordance with COPSOQ guidelines (Pejtersen et al., 2010). For all scales included, except for job security, a higher score represents better working conditions. To evaluate statistical differences in the years 2010-2012, independent group t-tests were used with the significance level set to 0.05. As a comparison group, data from a survey of 3517 workers aged 20-60 from the Danish National Research Center for the Work Environment in 2004 (NFA, 2005) are presented. There were about 360 answers from Danish industrial workers for each item.

\section{Results}

Managerial practices interpreted as instrumental for supporting sustainable working conditions under lean manufacturing are presented in Table 2. The four major categories 
Table 2 Summary of managerial practices identified as supporting sustainable working conditions during VPC's lean transformation [inspired by Pettigrew's (1987) framework for transformation of firms]

\section{Identified managerial practices}

\section{Coherent lean approach}

- Structured implementation with clear ownership

- Clear directions and a long-term perspective

- Locally adapted lean approach

\section{Value-creating leadership style \\ - Caring leadership \\ - Participatory promoting leadership \\ - Simultaneous production and employee focus}

\section{Conscious employee involvement \\ - Conscious and stepwise increases in employee involvement \\ - Integration of top-down and bottom-up initiatives}

\section{Promoting meaningful jobs and health}

- Conscious employment and competence strategy

- Promoting favorable work content

- Partial integration of lean and work environment management

\section{Examples of managerial practices to build commitment and health}

Providing structures, clear goals, and vision

Follow-ups and repeated communication about visions and goals

\section{Caring for employee working conditions, engagement, possibilities for development and health \\ Caring for secure jobs and counteracting wor- ries about losing one's job \\ Providing health benefits \\ Bridging: listening and translating \\ Building mutual trust \\ Emphasizing and repeating corporate values Making lean a joint goal and often referring to what both the company and the employees gain from lean}

Providing opportunities to be involved in a structured way depending on group skills and abilities

Strategies to keep up the lean practices and commitment

Making things easy

Employee bonuses

Lean coordinators consciously coordinates and integrates top-down and bottom-up initiatives

Employee development plans and cross-training Payroll system that encourages job rotation Encouraging employees to take on new tasks when jobs are simplified

Delegating administrative tasks

Providing support when needed

Focusing on product quality and employee skills

Promoting a meaningul work

Integrated monitoring of how changes affect work environment

Organizational context: Rather mature organization; well-functioning with structure and established social structures and work environment management, change experience, change competence, and readiness for change.

of practices were a coherent lean approach, a value-creating leadership style, conscious involvement, and focus on promoting meaningful jobs and health. Each is exemplified below with practices related to building commitment and health during the transformation process. Organizational context factors deemed as supporting for socially sustainable lean transformation are summarized at the bottom of the table. 


\section{Coherent lean approach}

Interviews with both managers and employees indicated that the company had a coherent lean approach with clear directions and a long-term perspective in their lean efforts. The organizational goals and vision, company values, lean goals, and work goals were clear, coherent, aligned, and well communicated, often repeated and acknowledged in the organization. In the interviews, employees were able to clearly express the company vision (doubled turnover in 2015), and what the management team wanted them to deliver in terms of good quality products and timely deliveries. The employees could not describe all the lean values by heart, but when the company's brochure with lean values was presented to them, the employees could describe what the values meant for their work and the company. For example, one employee stated: 'it should come with the right quality from each individual'. Their lean organization was steady and well-structured with active ownership from two lean coordinators and support from the CEO. To keep up the practices when support from the national lean program ceased, a long-term consultant was engaged. The lean coordinators met monthly with him to discuss lean experiences and strategies. Lean was viewed as a means of achieving the company's overall goal of growth and competitiveness, and the PM regularly had to report about their lean work and its progress to the executive group.

\section{Value-creating leadership style}

The company used a value-creating leadership style, comprised of promoting participation and caring leadership with a simultaneous focus on production and employee development and health. The simultaneous focus on production and the employees' health and development seemed to permeate the managerial practices. For example, the company's overall vision to grow conveyed a positive future state of the organization and was communicated as a joint goal for the company and the employees. Employees would therefore benefit from bonuses and job security. Furthermore, when talking about job rotation, the PM said it would make the company less vulnerable and would also benefit the employees through higher salaries and greater variation, plus make it easier for them to take time off. In addition, the managers often referred to what both the company and the employees had gained from the changes made-for example, in speaking about a machine investment, the PM said:

This is probably the best rationalization we have ever done in the company. In one product I think we saved XX SEK a year. The production time was reduced by $60 \%$, I think. And the lead time decreased. And became easier and better for the work environment. It is an ingenious idea. And it fits everybody. Everybody is more satisfied.

The caring leadership appeared to contribute to employees' engagement in development work. Bridging, structuring, listening, caring, and building mutual trust are behaviors that managers described in relation to their employees, and this was confirmed in employee interviews. For example, managers believed employees had useful knowledge about their jobs, which they encouraged them to share. Furthermore, they consciously counteracted resistance to change, provided clear directions, helped interpret situations and solve 
misunderstandings, provided timely feedback, gave the employees time to learn new skills and become accustomed to new tasks and technology, and helped prepare them for changes ahead. For example, after a lean-game, employees concluded that lean was about staff reduction. The CEO picked up on this misunderstanding and reassured them that it was not about reducing staff, but rather about efficient organization of production. These actions by the managers contributed to the formation of trust. Furthermore, the CEO seemed to genuinely care for his employees. He voiced concerns about employees' health and work environment issues. He viewed wellness benefits, in particular, as a way of caring for his employees and demonstrating their importance to the company, in addition to promoting better performance and health. Moreover, the CEO stated that he wanted the company to grow, but would not make any changes that would negatively affect employees. Being able to address employee concerns, by for example caring and actively counteracting concerns about losing one's job, appeared to contribute to employee engagement in improvement practices and their self-reported working conditions. In the following quote, the CEO demonstrates his attention to worker concerns about losing their jobs due to lean:

\begin{abstract}
Yes, that tool is probably earned already in a year or something. On the other hand, it takes away working hours, and then you have to be able to fill it with more products or something; otherwise, the employee sort of thinks that he will lose the job. It is based of course on the company growing, so they are not afraid to rationalize these boring and monotonous jobs.
\end{abstract}

The questionnaire data confirmed that job insecurity remained low over time (Table 3). High levels of trust, commitment, and quality of leadership were also maintained, while justice and respect significantly improved (Table 3).

Table 3 Employees' perceived psychosocial conditions regarding leadership, trust, and community

\begin{tabular}{|c|c|c|c|c|c|c|}
\hline \multirow[t]{2}{*}{ Scales $^{\mathrm{a}}$} & \multicolumn{6}{|c|}{ Year } \\
\hline & $\begin{array}{l}2010 \\
\text { Mean }\end{array}$ & $\begin{array}{l}2011 \\
\text { Mean }\end{array}$ & $\begin{array}{l}2012 \\
\text { Mean } \\
\end{array}$ & $\begin{array}{l}\text { Danish }^{b} \\
\text { Mean }\end{array}$ & $\begin{array}{c}\text { p-value } \\
2010-2012\end{array}$ & $95 \% \mathrm{Cl}^{\mathrm{c}}$ \\
\hline Quality of leadership & 65.3 & 62.8 & 69.1 & 52 & 0.395 & {$[-12.7$ to 5.1$]$} \\
\hline $\begin{array}{l}\text { Vertical trust-employee and } \\
\text { managers }\end{array}$ & 76.4 & 75.0 & 81.7 & 63 & 0.192 & {$[-13.5$ to 2.8$]$} \\
\hline $\begin{array}{l}\text { Horizontal trust between } \\
\text { employees }\end{array}$ & 76.4 & 76.4 & 80.4 & 66 & 0.352 & {$[-12.8$ to 4.7$]$} \\
\hline Justice and respect & 64.2 & 64.0 & 74.9 & 57 & $0.007^{*}$ & {$[-18.3$ to -3.1$]$} \\
\hline $\begin{array}{l}\text { Commitment to the } \\
\text { workplace }\end{array}$ & 71.2 & 69.8 & 78.4 & 59 & 0.087 & {$[-\mid 5.5$ to $||]$.} \\
\hline Social community at work & 87.5 & 88.0 & 91.3 & 80 & 0.240 & {$[-10.4$ to 2.7$]$} \\
\hline Job insecurity & 16.0 & 21.2 & 19.5 & 29 & 0.422 & {$[-12.2$ to 5.2$]$} \\
\hline
\end{tabular}

a The scale is 0-100. A higher score indicates a higher level of satisfaction, except for job insecurity where the results are supposed to be low.

b Mean scores for Danish industrial workers (NFA, 2005) are presented as reference values.

' $T$-tests are made between baseline and two-year follow-up.

$\mathrm{Cl}=$ confidence interval.

* $p<0.05$. 
The PM was supportive of his employees in special or urgent production processes, as the first-line manager illustrated:

If I have a problem, I go to the PM, or whom it concerns, but mostly I turn to the PM and talk to him, and then he usually solves it, if it is solvable. Or we help one another to solve it. So to speak, it works well. There is no 'this is not possible. 'No 'you have to solve that on your own.' There is always some support you can get if something goes wrong.

\section{Conscious employee involvement}

According to the interviews, VPC involved their employees consciously in the improvement practices, by providing stepwise increased opportunities in which employees could be involved according to their skill and ability. The managers promoted participation through providing structures that enabled involvement alongside a value-creating approach that encouraged employees. This conscious participation, along with the ability to coordinate and integrate top-down and bottom-up initiatives in a well-balanced manner, were interpreted as important factors in the transformation and for employee commitment. The PM had a key role as the one who balanced and integrated both the top-down and bottom-up initiatives. Furthermore, the lean coordinators consciously provided different support to different groups according to their maturity level. For example, one working group with low writing skills got extra support from the lean coordinators. In addition, they were aware that the improvement practices needed to be maintained and encouraged, and had the strategies to maintain lean practices, as the PM noted:

Our role is to keep the practices up-that it is always up to date, that you always work with improvements. You need some new ideas of course, otherwise it gets too boring. [...] Could be that the staff take part in VSM or in various improvement teams.

Employees indeed described that the PM often reminded them to continuously improve and that improvements were part of daily operations. For example, an employee described how an employee suggestion could be further developed:

'It is when you work with something, and you come to think of how it could be done instead.' [Colleagues were then consulted]: 'What do you think about this?' [After a discussion in the group, the employee then forwards the idea to the industrial engineers or to whom it belongs.] 'Then things usually start to happen.'

From employee and manager interviews, four main stages in the development of employee involvement in improvement practices can be identified:

1. Prior to lean, the company had a consultation system for improvements in which one person was assigned to collect suggestions from employees by asking questions like-What do you need to make your job $10 \%$ faster?

2. The company successfully gathered suggestions in meetings and personal encounters by asking questions like-What product is especially bothersome? What can we simplify? What can we do that is less harmful to ourselves? 
3. Improvement teams for special problems had been operating since 2010 .

4. CIs were integrated into the employees' regular weekly meetings, with a set agenda to discuss topics such as work disturbances and quality deviations, and suggestions on how to prevent them.

Moreover, lean coordinators assigned interdisciplinary teams of employees to solve specific work problems. To engage as many employees as possible in lean and to build commitment, the lean coordinators consciously made things easy. Monetary group bonuses, aligned with performance goals, were also used to create commitment and steer toward company goals. Furthermore, they viewed the employee bonuses and handling improvement suggestions from employees promptly as ways of maintaining commitment.

\section{Promoting meaningful jobs and health}

The managers had active strategies to support meaningful jobs by promoting rich work content, providing structures for employee development, and through being considerate and working strategically with employees' work environment and health. The management allocated time for improvement work and strongly believed in lean's potential to jointly improve the work environment and the company's competitiveness, as the PM illustrated:

If we set aside time for improvement work, you always got the time back, because it gave something-a product takes less time, the quality will be better, the work environment will be better.

The CEO stated that the company's employee development strategy was hiring the right workers, provide them opportunities to develop, and keeping them engaged and competent so that they do not leave the company to develop elsewhere. To aid development, he made sure to employ three generations so workers could learn from one other. The $\mathrm{CEO}$ also believed in delegating tasks to those whom they concerned. Managers also actively encouraged employees to take on other, more difficult tasks. This was especially true when work tasks became simplified, for example, as a result of standardization or technical improvements. In addition, the payroll system encouraged job rotation. During low-production seasons, managers encouraged and trained employees to rotate to other jobs. The company also paid higher salaries to multiskilled workers. Employee interviews confirmed managements' support for their development. The CEO believed that the fact that employees had noticed that they had an impact on the improvement practices, and that it had resulted in increased earnings and a better work environment, had contributed to the commitment to change within the company. Similarly, the PM remarked on how being able to contribute through finding better work solutions was another motivating type of employee development:

I also think you get employees that are more motivated, that you don't need to sit and work for 40 hours in a row, all the time, but there is always something, where you get to use your creativity and contribute to [ideas and improvements and he provides examples 
of employee suggestions .... I think most people have been involved and contributed, to something at least.

An example of work environmental focus in their lean system was the integrated log of how major improvements had affected the work environment. According to the KPIs, about one-third of the major production changes had also improved working conditions. Another example was the questions asked in connection to the improvement practices, about how to make work less harmful. In sum, several of the company's managerial practices appeared to support meaningful work content and achievement of both company and employee goals.

\section{Discussion}

This case study set out to provide an understanding of how SSWCs can be supported by management during a lean transformation. Managerial practices supporting SSWC, and contextual factors that could have influenced the results, are discussed below.

\section{Managerial practices supporting SSWC}

The findings of this case study have contributed to a better understanding of the interactive and mutually dependent relationships between work context, managerial practices, lean practices, and employee engagement in change, and how these support SSWC. In the present company, SSWC seemed to be dependent on the joint existence of a beneficial work context, and managerial practices succeeding in consciously integrating topdown and bottom-up perspectives. Thus, engagement in change was supported. These managerial practices are similar to the activities Kira and van Eijnatten (2009) suggested as important for supporting SSWC. The company had, for example, developed an improvement system that enabled constant organizing and consciously involved and empowered the employees. Furthermore, the value-creating leadership style, in combination with a focus on meaningful jobs, provided employees with important job resources such as opportunities to influence job design, to grow, and to undertake more skilled tasks. Their coherent lean approach is thought to contribute to SSWC by shaping clear roles and contributing to employees' understanding of how they can contribute to the company's strategic goals. This has been linked to job satisfaction and employee retention (Boswell, 2006).

Since CIs are at the heart of lean (Liker, 2004), and employees are often expected to contribute with their on the job expertise, the participative approach with conscious involvement seems to be crucial in facilitating employee engagement in change. This may, in turn, potentially aid in sustaining lean practices. The authors suggest that one success factor in managers' abilities to build trust and increase employees' commitment to change was the employees seeing how the changes improved their own work. This finding is in line with that of previous studies who indicated that employees need to perceive that spending time on CIs can 'help them in their work' (Rapp \& Eklund, 2002, p. 968), and that employee perceived changes of daily work procedures are important for increased job satisfaction (Nielsen \& Randall, 2012). 
In a similar vein, the company's manifested commitment to employee health and working conditions through systematic processes for work environment management and health benefits may have served as an incentive for employee engagement and contributed to the good relations in the company. For example, health benefits were viewed by managers as a way of caring for their employees. Sørensen et al. (2011) suggested that such a symbolic action can be a useful strategy where trust is threatened by an organizational change initiative like lean. This type of systematic and considerate management of the work environment has been associated with health-related sustainability (Dellve et al., 2008). Thus, this already 'built in' systematic focus on work environment and health may have somewhat compensated for lean's lack of health-promotion focus, and thereby aided in counteracting negative effects of lean. This aspect is rarely mentioned in the lean literature. Lean initiatives associated with more positive outcomes have instead been attributed to focus on human resources in general (Longoni et al., 2013) and management approaches (Westgaard \& Winkel, 2011).

The company's value-creating leadership style has many of the characteristics of transformational leadership (Bass, 1990), and was exemplified by their shared positive vision, the leader as a role model, and individualized consideration. Value for employees was supported in several ways, for example, by promoting development and learning, which was classified by Liker and Hoseus (2008) as managerial value-adding work. The term value-creating was chosen during the analysis since the managers' caring approach seemed to go beyond transformational leadership. They prioritized creating value for the employees in the forms of being available, a key factor for healthy change (Saksvik et al., 2007), caring for their health, growth, and participation, and promoting a meaningful job. Furthermore, the employees were, consistent with Wright et al. (2001), viewed as an important resource in achieving company goals. The managers were both considerate and supportive, looked out for the welfare of their employees, and provided structure through clear directions and bonuses, which may have contributed to the commitment in CIs. Furthermore, the term value-creating builds on Emiliani's (1998) definition of lean leadership as 'behaviors that create value' (p. 619). By talking about managerial work in terms of adding value, we believe that value for employees can be made more visible, and thereby more easily analyzed alongside other value-adding activities. Comparing the managers' approaches to ideal activities for lean leaders, as described by Liker and Convis (2012), we conclude that the managers at VPC came close to that description by, for example, living the company values, having closeness and familiarity with work practices, having strategies for developing others, supporting kaizen, and designing a coherent lean system. Just like with other companies, VPC ran into problems during its implementation. In the present study, they are somewhat reflected in how the managers solved the difficulties. For example, the managers had active strategies to maintain the momentum for change, which otherwise might have had a tendency to decline over time (Senge, 1999).

\section{Contextual factors influencing SSWC}

The present study points to the complexity of components interacting to shape working conditions, and how supportive management and leadership practices can positively 
affect the outcome. However, from this study, it is not possible to draw conclusions about what factors were more important. The managers seemed to have high people and change management competence, both through experience from previous change projects, lean courses provided by the national program and support through coaches from the program and their long-term consultant. Hence, the company's organizational maturity probably aided in shaping a coherent, structured, and adapted lean system. The alignment of strategy, processes, structures, and activities formed a stable entity, all of which have been proposed as being important for health in an organization (von Thiele Schwarz \& Hasson, 2013) and for sustainable lean initiatives (Hines, 2011). Since lean may impact work environments differently during different tasks (Benders et al., (2016), the fact that the present company engaged in small-scale skilled production rather than less skilled production-line work may have contributed to the positive outcomes seen in the results. Most previous studies of lean in industry reporting negative impacts on the work environment have studied less qualified industrial tasks. Furthermore, opportunities for building trust and commitment may have been affected by the fact that the present company was family owned and that the mangers were close to the production.

The company had active strategies for supporting meaningful jobs with opportunities for development and work variation, thereby counteracting the presumably negative effects of lean on work content. Since job resources, like employee opportunities for rich work content and development are important factors for employee health (Bakker \& Demerouti, 2007), and central components of a regenerative work (Kira \& Forslin 2008), their systematic and active focus on promoting meaningful jobs and employee health are thought to contribute to SSWC. These values are also emphasized in the Nordic tradition of sociotechnical job design, where worker democratization, employee involvement, and collaboration with unions are central characteristics (Johansson \& Abrahamsson, 2009). VPC seemed, like several other Nordic companies (Börnfelt, 2006; Sederblad, 2013; Seppälä \& Klemola, 2004), to have adopted more of a hybrid version of lean with stronger sociotechnical ingredients. Human values and principles emphasized in sociotechnical work design (Cherns, 1987; Klein, 2014), such as congruent practices, opportunities to learn, and good social support, were present in VPC's lean approach. Similarly, the study by Seppälä and Klemola (2004), conducted in a Finnish company with highly skilled metal workers, as in the present study, suggests that the expanded and more challenging jobs they found were the result of a combination of a sociotechnical approach and lean thinking.

Outer contextual factors were not studied in detail. But outer factors that may have contributed to VPC's lean transformation were the dual legitimacy from: both the employer's organization and the union within the national support program and the lean support program itself, which provided support for the managers. The possibilities of generalizing from a case study are limited. The company context and specific conditions must be considered when transferring the results to other companies (Fishman, 1999). The triangulation of methods, and the fact that all data in this study pointed in the same direction strengthened the data's internal validity. In future research, an interesting question to further explore is what are the management practices or contextual factors that may mediate the relationship between leadership and health. 


\section{Practical implications}

The practical implications that can be drawn from the present study are summarized below:

- Adopt a value-creating leadership approach that supports employee participation, engagement, and health at work;

- Care for employees and their competence development and work environment, since caring is a crucial key for engagement;

- Consider employee development both through their primary work tasks and CIs, and actively monitor and counteract any negative effects on the work characteristics;

- Encourage participation, but consciously, and in a stepwise fashion involve employees according to their maturity and skills;

- Ensure that the focus on production and employee health is balanced and systematically integrated into the management system to promote favorable work characteristics.

\section{Conclusion}

Previous studies on managerial practices under lean manufacturing indicate that more human oriented lean-approaches with a focus on human resources may have more favorable outcomes for the employees. This study provides understanding of how managerial practices can support social sustainability under lean manufacturing. The results illustrate the interactive relationships between managerial practices, lean practices, and employee engagement in change. The hybrid version of lean with strong sociotechnical ingredients supported the quality of work and human values in the organization, even under lean production. Value-creating leadership was integrating important sociotechnical perspectives, for example, supporting meaningful jobs with opportunities to grow, conscious employee involvement with active strategies for considering and integrating top-down and bottom-up initiatives. The organizational maturity, company culture, and change competence also had importance. In addition, the company's systematic focus on work environment and health may have aided in counteracting negative effects of lean. The findings indicate that managerial practices actively supporting important job resources as an integral part of the lean system may aid in supporting SSWCs.

\section{References}

Alvesson, M. \& Sveningsson, S. (2003). Managers doing leadership: the extra-ordinarization of the mundane, Human Relations, 56: 1435-1459, doi: http://dx.doi. org/10.1177/00187267035612001.

Andreasson, J., Eriksson, A. \& Dellve, L. (2015). Health care managers' views on and approaches to implementing models for improving care processes. Journal of Nursing Management, 24, 219-227, doi: http://dx.doi.org/10.1111/jonm.12303.

Bakker,A.B.\&Demerouti,E. (2007).The JobDemands-Resources model: state of the art, Journal of Managerial Psychology, 22, 309-328, doi: http://dx.doi.org/10.1108/02683940710733115.

Bass, B. M. (1990). From transactional to transformational leadership: Learning to share the vision, Organizational Dynamics, 18: 19-31, doi: http://dx.doi.org/10.1016/00902616(90)90061-S. 
Benders, J., Bleijerveld, H., \& Schouteten, R. 2016. Continuous improvement, burnout and job engagement: a study in a Dutch nursing department. The International Journal of Health Planning and Management [Online]. Retrieved from doi: http://dx.doi. org/10.1002/hpm.2355.

Boswell, W. (2006). Aligning employees with the organization's strategic objectives: out of 'line of sight', out of mind, The International Journal of Human Resource Management, 17: 1489-1511, doi: http://dx.doi.org/10.1080/09585190600878071.

Brandao De Souza, L. 2009. Trends and approaches in lean healthcare, Leadership in Health Services, 22: 121-139, doi: http://dx.doi.org/10.1108/17511870910953788.

Brännmark, M. \& Eklund, J. (2013). Leaninspirerade förändringar och personalens upplevelser. [Lean-inspired changes and employee experiences], in Sederblad, P. (ed.) Lean i arbetslivet [Lean in working life]. Stockholm: Liber.

Brännmark, M. \& Håkansson, M. 2012. Lean production and work-related musculoskeletal disorders: overviews of international and Swedish studies. Work: A Journal of Prevention, Assessment and Rehabilitation, 41, 2321-2328, doi: http://dx.doi.org/10.3233/wor2012-0459-2321.

Börnfelt, P.-O. 2006. Förändringskompetens på industrigolvet : kontinuerligt förändringsarbete $i$ gränslandet mellan lean production och socioteknisk arbetsorganisation. [Change competence on the shop floor: Continuous change work in the borderland between lean production and socio-technical work organisation]. Doctoral thesis, Gothenburg University.

Cherns, A. 1987. Principles of Sociotechnical Design Revisted. Human Relations, 40, 153161.

Corin, L. \& Björk, L. (2016). Job demands and job resources in human service managerial work an external assessment through work content analysis. Nordic Journal of Working Life Studies, 6(4), 3-28. doi: http://dx.doi.org/10.19154/njwls.v6i4.5610.

Dellve, L., Skagert, K. \& Eklöf, M. 2008. The impact of systematic occupational health and safety management for occupational disorders and long-term work attendance. Social Science \& Medicine, 67, 965-970, doi: http://dx.doi.org/10.1016/j.socscimed.2008.05.030.

Demerouti, E., Bakker, A. B., Nachreiner, F., and Schaufeli, W. B. (2001). The job demandsresources model of burnout. Journal of Applied Psychology, 86(3): 499-512, doi: http:/dx.doi.org/10.1037/0021-9010.86.3.499.

Denis, J.-L., Lamothe, L. \& Langley, A. (2001). The dynamics of collective leadership and strategic change in pluralistic organizations, Academy of Management Journal, 44: 809_ 837, doi: http://dx.doi.org/10.2307/3069417.

Dennis, P. (2007). Lean Production Simplified: A Plain Language Guide to the World's Most Powerful Production System, New York, Productivity Press.

Dul, J., Bruder, R., Buckle, P., Carayon, P., Falzon, P., Marras, W. S., Wilson, J. R. \& Van Der Doelen, B. (2012). A strategy for human factors/ergonomics: developing the discipline and profession, Ergonomics, 55: 377-395, doi: http://dx.doi.org/10.1080/00140139.20 12.661087.

Eklund, J. (1998). Work conditions and company strategies, in: Vink, P., Koningsveld, E. \& Dhondt, S. (eds.) Human Factors in Organizational Design and Management - IV, North-Holland: Amsterdam, pp. 263-268.

Emiliani, M. L. (1998). Lean behaviors, Management Decision, 36: 615-631, doi: http: $/ \perp$ dx.doi.org/10.1108/00251749810239504.

Eriksson, A., Holden, R. J., Williamsson, A. \& Dellve, L. 2016. A Case Study of Three Swedish Hospitals' Strategies for Implementing Lean Production. Nordic Journal of Working Life Studies, 6, 105-131, doi: http://dx.doi.org/10.19154/njwls.v6i1.4912.

Eurofound (2012). Fifth European Working Conditions Survey. Luxembourg: Publications Office of the European Union. Retrieved from http://www.eurofound.europa.eu/sites/default/files/ef publication/field ef document/ef1182en.pdf. 
Fishman, D. B. (1999). The Case for Pragmatic Psychology, New York, University Press.

Graneheim, U. H. \& Lundman, B. 2004. Qualitative content analysis in nursing research: concepts, procedures and measures to achieve trustworthiness, Nurse Education Today, 24: 105-112, doi: http://dx.doi.org/10.1016/j.nedt.2003.10.001.

Gylling Olesen, K., Thoft, E., Hasle, P. \& Kristensen, T. S. (2008). Virksombedens sociale kapital. Hvidbog [Organizational social capital], Copenhagen, Det nationale Forskningscenter for Arbejdsmiljo.

Hasle, P. (2014). Lean production-an evaluation of the possibilities for an employee supportive lean practice, Human Factors and Ergonomics in Manufacturing \& Service Industries, 24: 40-53, doi: http://dx.doi.org/10.1002/hfm.20350.

Hasle, P., Bojesen, A., Langaa Jensen, P. \& Bramming, P. (2012). Lean and the working environment: a review of the literature, International Journal of Operations \& Production Management, 32: 829-849, doi: http://dx.doi.org/10.1108/01443571211250103.

Hasle, P. \& Paarup Nielsen, A. (2013). Lean och ledarskap i praktiken. [Lean and leadership in practice], in: Sederblad, P. (ed.) Lean i arbetslivet. Stockholm: Liber.

Hillberg, J. (2012). Sweden's take on Lean, Lean management journal [Online]. Available: http://www.produktionslyftet.se/filer/docs/LMJ 2012.PDF.

Hines, P. (2011). Staying Lean: Thriving, Not Just Surviving, New York, Productivity Press.

Hines, P., Holweg, M. \& Rich, N. 2004. Learning to evolve: A review of contemporary lean thinking, International Journal of Operations \& Production Management, 24: 994-1011, doi: http://dx.doi.org/10.1108/01443570410558049.

Holden, R. J. 2011. Lean Thinking in Emergency Departments: A Critical Review. Annals of Emergency Medicine, 57, 265-278, doi: http://dx.doi.org/10.1016/j.annemergmed.2010.08.001.

Hosking, D. M. (1988). Organizing, leadership and skilful process, Journal of Management Studies, 25: 147-166, doi: http://dx.doi.org/10.1111/j.1467-6486.1988.tb00029.x.

Håkansson, M., Dellve, L., Waldenström, M. \& Holden, J. R. 2017. Sustained lean transformation of working conditions: A Swedish longitudinal case study. Hum Factors Man. [Online]. Retrieved from doi: https://doi.org/10.1002/hfm.20710.

Jackson, P. R., \& Mullarkey, S. 2000. Lean production teams and health in garment manufacture. J Occup Health Psychol, 5, 231-45, doi: http://dx.doi.org/10.1037/1076-8998.5.2.231.

Johansson, J. \& Abrahamsson, L. (2009). The good work - A Swedish trade union vision in the shadow of lean production, Applied Ergonomics, 40: 775-780, doi: http://dx.doi. org/10.1016/j.apergo.2008.08.001.

Kira, M. \& Forslin, J. (2008). Seeking regenerative work in the post-bureaucratic transition, Journal of Organizational Change Management, 21: 76-91, doi: http://dx.doi. org/10.1108/09534810810847048.

Kira, M. \& Van Eijnatten, F. M. (2009). Sustained by work: Individual and social sustainability, in: Docherty, P., Kira, M. \& Shani, A. B. (eds.) Creating Sustainable Work Systems: Developing Social Sustainability, New York: Routledge, pp. 233-246.

Kivimäki, M., Elovainio, M., Vahtera, J. \& Ferrie, J. E. (2003). Organisational justice and health of employees: prospective cohort study, Occupational and Environmental Medicine, 60: 27-34, doi: http://dx.doi.org/10.1136/oem.60.1.27.

Klein, L. 2014. What do we actually mean by 'sociotechnical'? On values, boundaries and the problems of language. Applied Ergonomics, 45, 137-142, doi: http://dx.doi. org/10.1016/j.apergo.2013.03.027.

Kompier, M. (2003). Job design and well-being, in: Schabracq, M., Winnubst, J. A. M. \& Cooper, C. L. (eds.) The Handbook of Work and Health Psychology, Chichester, West Sussex, England: J. Wiley \& Sons.

Kotter, J. P. (1990). A Force for Change: How Leadership Differs from Management, New York, Free Press. 
Kotter, J. P. (1996). Leading Change, Boston, Mass., Harvard Business School Press.

Koukoulaki, T. (2014). The impact of lean production on musculoskeletal and psychosocial risks: An examination of sociotechnical trends over 20 years, Applied Ergonomics, 45: 198-212, doihttp://dx.doi.org/10.1016/j.apergo.2013.07.018.

Kristensen, T. S. (1999). Challenges for research and prevention in relation to work and cardiovascular diseases, Scandinavian Journal of Work, Environment \& Health, 25: 550557, doi: http://dx.doi.org/10.2307/40966947.

Kvale, S. \& Brinkmann, S. (2009). InterViews: Learning the Craft of Qualitative Research Interviewing, Los Angeles, Sage Publications.

Landsbergis, P. A., Cahill, J. \& Schnall, P. (1999). The impact of lean production and related new systems of work organization on worker health, J Occup Health Psychol, 4: 108-30, doi: http://dx.doi.org/10.1037/1076-8998.4.2.108.

Langstrand, J., (2012). Exploring organizational translation: a case study of changes toward Lean Production. Diss. Linköping: Linköping University. Available: http://liu.diva-portal. org/smash/get/diva2:503206/FULLTEXT03.pdf.

Lewchuk, W., Stewart, P., \& Yates, C. (2001). Quality of working life in the automobile industry: A Canada-UK comparative study. New Technology, Work and Employment, 16, 72-87, doi: http://dx.doi.org/10.1111/1468-005X.00078.

Liker, J. K. (2004). The Toyota Way: 14 Management Principles from The World's Greatest Manufacturer, New York, McGraw-Hill.

Liker, J. K. \& Convis, G. L. (2012). The Toyota Way to Lean Leadership: Achieving and Sustaining Excellence through Leadership Development, New York, McGraw-Hill.

Liker, J. K. \& Hoseus, M. (2008). Toyota Culture: The Heart and Soul Of The Toyota Way, New York, McGraw-Hill.

Longoni, A., Pagell, M., Johnston, D. \& Veltri, A. (2013). When does lean hurt? - an exploration of lean practices and worker health and safety outcomes, International Journal of Production Research: 1-21, doi: http://dx.doi.org/10.1080/00207543.2013.765072.

Mann, D. (2009). The missing link: Lean leadership, Frontiers of Health Services Management, 26: 15-26.

Mehri, D. (2006). The darker side of lean: An insider's perspective on the realities of the Toyota production system, Academy of Management Perspectives, 20: 21-42, doi: http: II dx.doi.org/10.5465/AMP.2006.20591003.

NFA (2005). NationalResarchCenter for the Work Environment. Psykisk arbejdsmiljo [Psychosocial work environment COPSOQ]. Retrieved from http://olddata.arbejdsmiljoforskning.dk/Nationale\%20Data/3DII.aspx?lang=da.

Nielsen, K. T. (1996). How strong are the links between new market conditions, new production principles, and better working conditions? International Journal of $\mathrm{Hu}$ man Factors in Manufacturing, 6, 21-28, doi: http://dx.doi.org/10.1002/(SICI)15227111(199624)6:1<21::AID-HFM2>3.0.CO;2-M.

Nielsen, K., Randall, R., Yarker, J. \& Brenner, S.-O. (2008). The effects of transformational leadership on followers' perceived work characteristics and psychological well-being: A longitudinal study, Work \& Stress, 22: 16-32, doi:http://dx.doi. org/10.1080/02678370801979430.

Nielsen, K. \& Randall, R. (2012). The importance of employee participation and perceptions of changes in procedures in a teamworking intervention, Work \& Stress, 26: 91-111, doi: http://dx.doi.org/10.1080/02678373.2012.682721.

Oudhuis, M., Tengblad, S., (2013). Experiences from implementation of lean production: standardization versus self-management: a Swedish case study, Nordic Journal of Working Life Studies, 3: 31-48, doi:http://dx.doi.org/10.19154/njwls.v3i1.2519.

Parker, S. K. 2003. Longitudinal effects of lean production on employee outcomes and the mediating role of work characteristics. J Appl Psychol, 88, 620-34, doi: http://dx.doi. 
org/10.1037/0021-9010.88.4.620.

Parker, S. K. (2014). Beyond motivation: job and work design for development, health, ambidexterity, and more, Annual Review of Psychology, 65: 661-691, doi: http://dx.doi. org/10.1146/annurev-psych-010213-115208.

Pejtersen, J. H., Kristensen, T. S., Borg, V. \& Bjorner, J. B. (2010). The second version of the Copenhagen Psychosocial Questionnaire, Scandinavian Journal of Public Health, 38: 8-24, doi: http://dx.doi.org/10.1177/1403494809349858.

Pettersen, J. (2009). Defining lean production: some conceptual and practical issues, The TQM Journal, 21: 127-142, doi: http://dx.doi.org/10.1108/17542730910938137.

Pettigrew, A. M. (1987). Context and action in the transformation of the firm, Journal of Management Studies, 24: 649-670, doi: http://dx.doi.org/10.1111/j.1467-6486.1987.tb00467.x.

Poksinska, B., Swartling, D. \& Drotz, E. (2013). The daily work of Lean leaders - lessons from manufacturing and healthcare, Total Quality Management \& Business Excellence, 24: 886-898, doi: http://dx.doi.org/10.1080/14783363.2013.791098.

Radnor, Z. \& Walley, P. (2008). Learning to walk before we try to run: adapting lean for the public sector, Public Money \& Management, 28: 13-20, doi: http://dx.doi.org/10.1111/ j.1467-9302.2008.00613.x.

Rapp, C. \& Eklund, J. (2002). Sustainable development of improvement activities - The long-term operation of a suggestion scheme in a Swedish company, Total Quality Management and Business Excellence, 13: 945-969, doi: http://dx.doi.org/10.1080/0954412022000017049.

Saksvik, P. Ø., Tvedt, S. D., Nytrø, K., Andersen, G. R., Andersen, T. K., Buvik, M. P. \& Torvatn, H. (2007). Developing criteria for healthy organizational change, Work \& Stress, 21: 243-263, doi: http://dx.doi.org/10.1080/02678370701685707.

Samuel, D., Found, P. \& Williams, S. J. (2015). How did the publication of the book The Machine That Changed The World change management thinking? Exploring 25 years of lean literature, International Journal of Operations \& Production Management, 35 : 1386-1407, doi: http://dx.doi.org/10.1108/IJOPM-12-2013-0555.

Saurin, T. A., \& Ferreira, C. F. (2009). The impacts of lean production on working conditions: A case study of a harvester assembly line in Brazil. International Journal of Industrial Ergonomics, 39, 403-412, doi: http://dx.doi.org/10.1016/j.ergon.2008.08.003.

Schaufeli, W. B. \& Bakker, A. B. (2004). Job demands, job resources, and their relationship with burnout and engagement: a multi-sample study, Journal of Organizational Behavior, 25: 293-315, doi: http://dx.doi.org/ 10.1002/job.248.

Schouteten, R., \& Benders, J. 2004. Lean Production Assessed by Karasek's Job Demand-Job Control Model. Economic and Industrial Democracy, 25, 347-373, doi: http://dx.doi. org/10.1177/0143831X04044831.

Sederblad, P. (ed.) (2013). Lean i arbetslivet. [Lean in working life], Stockholm: Liber.

Sederblad, P. \& Abrahamsson, L. (2013). Avslutning. [Final Thoughts], in: Sederblad, P. (ed.) Lean i arbetslivet [Lean in working life], Stockholm: Liber.

Senge, P. (1999). The Dance of Change: The Challenges of Sustaining Momentum in Learning Organizations, London, Nicholas Brealey.

Seppälä, P. \& Klemola, S. (2004). How do employees perceive their organization and job when companies adopt principles of lean production? Human Factors and Ergonomics in Manufacturing \& Service Industries, 14: 157-180, doi: http://dx.doi.org/10.1002/ hfm.10059.

Shah, R. \& Ward, P. T. (2003). Lean manufacturing: context, practice bundles, and performance, Journal of Operations Management, 21: 129-149, doi: http://dx.doi.org/10.1016/ S0272-6963(02)00108-0.

Shah, R. \& Ward, P. T. (2007). Defining and developing measures of lean production, Journal of Operations Management, 25: 785-805, doi: http://dx.doi.org/10.1016/j. jom.2007.01.019. 
Skakon, J., Nielsen, K., Borg, V. \& Guzman, J. (2010). Are leaders' well-being, behaviours and style associated with the affective well-being of their employees? A systematic review of three decades of research, Work \& Stress, 24: 107-139, doi: http://dx.doi.org/10.108 $0 / 02678373.2010 .495262$.

Spector, P. E. (1986). Perceived control by employees: a meta-analysis of studies concerning autonomy and participation at work, Human Relations, 39: 1005-1016, doi: http://dx. doi.org/10.1177/001872678603901104.

Stake, R. E. (1995). The Art of Case Study Research, Thousand Oaks, California, Sage.

Sørensen, O. H., Hasle, P. \& Pejtersen, J. H. 2011. Trust relations in management of change. Scandinavian Journal of Management, 27, 405-417, doi: http://dx.doi.org/10.1016/j.scaman.2011.08.003.

Tengblad, S. (2012). The work of managers: Towards a practice theory of management, Oxford, Oxford University Press.

Torvatn, H. Y., Sørensen, O. H., Talja, H. \& Eriksen, B. (2015). Good Nordic Management Practices: State of the Art, Vol. 2015:525. Nordic Council of Ministers.

Von Thiele Schwarz, U. \& Hasson, H. 2013. Alignment for achieving a healthy organization. In: Bauer, G. F. \& Jenny, G. J. (eds.) Salutogenic Organizations and Change : The Concepts Behind Organizational Health Intervention Research. Dordrecht: Springer.

Vänje, A. \& Brännmark, M. (2015). Walking around the pyramids: Managers' shop-floor activities in Lean-inspired organizations, Economic and Industrial Democracy [Online]. Available:http://eid.sagepub.com/content/early/2015/04/29/0143831X15580351.abstract.

Waldenström, K. (2007). Externally assessed psychosocial work characteristics : a methodological approach to explore how work characteristics are created, related to self-reports and to mental illness, Doctoral thesis, Stockholm: Karolinska Institutet.

Westgaard, R. H. \& Winkel, J. (2011). Occupational musculoskeletal and mental health: Significance of rationalization and opportunities to create sustainable production systems A systematic review, Applied Ergonomics, 42: 261-296, doi: http://dx.doi.org/10.1016/j. apergo.2010.07.002.

Womack, J. P. \& Jones, D. T. (2003). Lean Thinking: Banish Waste and Create Wealth in Your Corporation, London, Free Press Business.

Womack, J. P., Jones, D. T. \& Roos, D. (1991). The Machine that Changed the World: [The Story Of Lean Production], New York, HarperPerennial.

Wright, P. M., Dunford, B. B. \& Snell, S. A. (2001). Human resources and the resource based view of the firm, Journal of Management, 27: 701-721, doi: http://dx.doi. org/10.1177/014920630102700607. 